\title{
RADICAL TPACIFR
}

A SOCIALIST, FEMINIST, AND ANTI-RACIST JOURNAL ON THE THEORY AND PRACTICE OF TEACHING

\section{Challenging a 'Warist' Society with Digital Peace Pedagogy}

\author{
by J. Ashley Foster and Andrew Janco
}

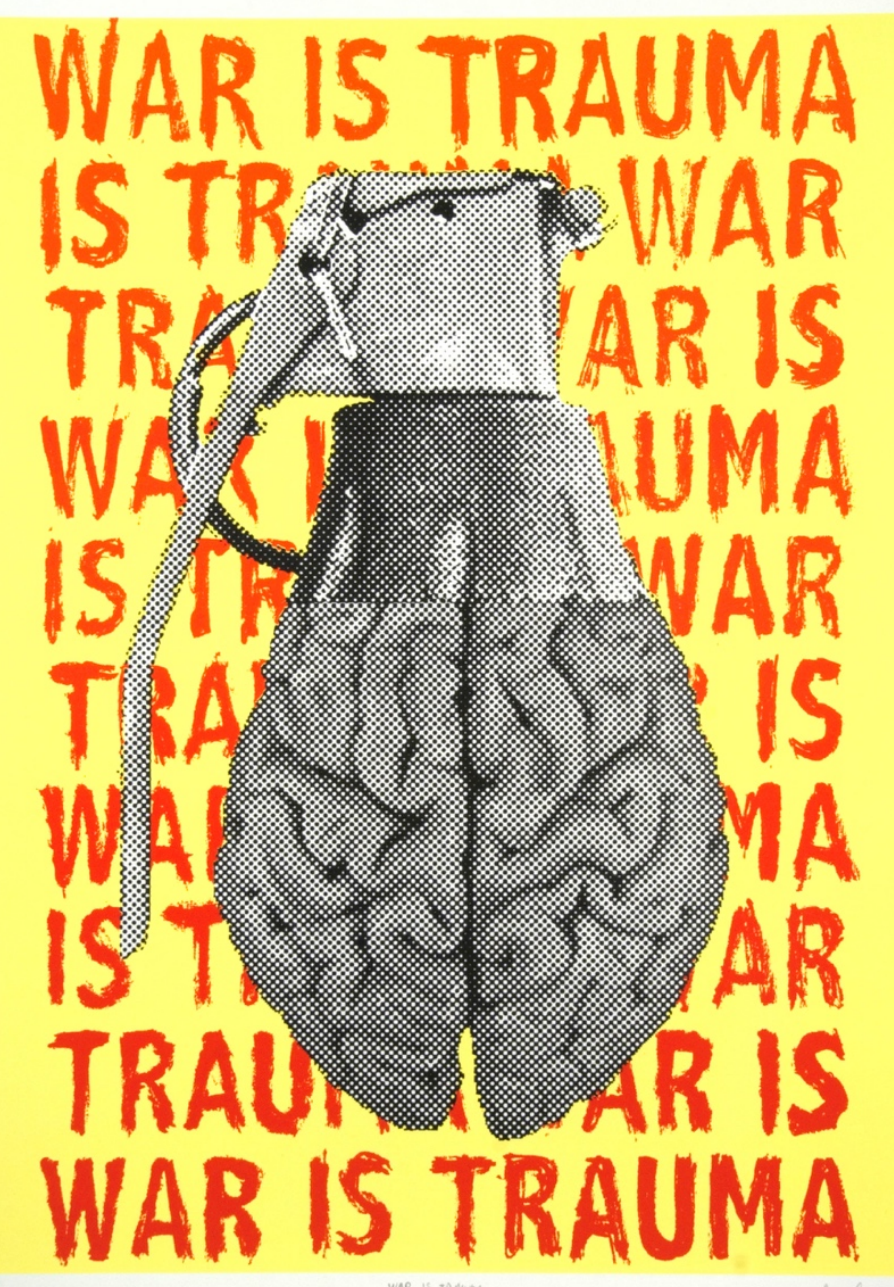


One issue contributing to division in the United States that could be changed, however, is the political polarization occurring nationwide... in the United States, political divisions have only grown deeper. Statistics website FiveThirtyEight tracked data from the most recent election only to find that counties across the country are becoming more extreme in their political leanings as evidenced by nationwide voting patterns (Wasserman). This is problematic because as communities become more unified in a singular ideology, it becomes harder to accept outside viewpoints, and as [Doris] Panzer would emphasize, it becomes harder to agree with others on what problems need to be addressed.

- Jake Kutchins, Final Paper, Peace Testimonies in Literature \& Art Spring 2017 Writing Seminar

Pacifist activism is not easy. It requires intense commitment and bravery. It asks a lot of its participants and cannot promise any substantial progress. A person must dedicate their life to the struggle for peace so that future generations don't have to. This kind of activism is truly selfless and dependent on a person's courage and devotion to helping others. However, it is absolutely necessary if we are to combat inequality and violence.

- Alyssa Kerper, Peace Testimonies in Literature \& Art Spring 2017 Writing Seminar

T his year marks the nineteenth anniversary of $9-11$, a day that changed contemporary history. It made ostensibly permissible the "War on Terror," what is now a nineteen-year violent involvement in the Middle East. The Watson Institute of Brown University announces that

All told, between 480,000 and 507,000 people have been killed in the United States' post-9/11 wars in Iraq, Afghanistan, and Pakistan. This tally of the counts and estimates of direct deaths caused by war violence does not include the more than 500,000 deaths from the war in Syria, raging since 2011, which the US joined in August 2014. (Crawford 1)

What this anniversary also means to the radical teacher in the United States is that, if many first-year students entering colleges are 18, these recent few years are the first mass matriculation of a generation of students born into a post-9-11 world. They have never not experienced the United States at war, and they certainly cannot remember first-hand the iconic images of the Twin Towers falling, the falling man leaping from the towers, or the public cry for militarization that ensued days after the attacks. Indeed, they have been born into what Paul Saint-Amour calls "perpetual inter-war," which "denote[s] not only 'between wars' but also 'in the midst of war"' (306). And even if most of our students experience peace because the war is "over there," they have been raised amidst what peace scholar
Duane Cady calls a "warist" society, where "war is both morally justified in principle and often morally justified in fact" (17)

One of the many consequences of a "warist" society is that it privileges a discourse of war over a discourse of peace. This is why, in response to a call for papers that features "Teaching about Capitalism, War, and Empire," we have decided to shift the emphasis to teaching peace. It becomes clear in studying peace theories that capitalism and empire, along with racism, sexism, and imperialism, are essential elements to address in order to create a world without war. In a warist society, "war is taken to be natural and normal. No other way of understanding large-scale human conflict even comes to mind" (Cady 22). It "obstructs questioning the conceptual framework of the culture" (22). Part of this obstruction is twofold: firstly, warism posits such an extreme version of pacifism, reliant on clichés and stereotypes, that an intellectually or morally viable pacifist theory becomes a large-scale impossibility. Secondly, the glory of war renders peace histories almost unteachable because they do not fit into normative discourses and social frames. Seen as impractical and utopian, even successful nonviolent struggles get cast to the periphery of education, reinforcing the ideals of a warist society. Subverting these ideals "involves recovery of lost or neglected history, consideration of a full range of options beyond traditional social constraints holding the forms of domination in place, and serious, systematic, and legitimized study of conditions constituting positive peace" (116). This is why the authors feel that, in the discussion of war, we need to include ways of constructively building peace. To this end, peace studies focuses on "positive peace," where peace is not simply the absence of war, but the active creation of a world that can sustain peace. Dr. Martin Luther King, Jr. makes the distinction in his famous "Letter from Birmingham Jail," where he compellingly argues that "negative peace... is the absence of tension" and a "positive peace... is the presence of justice. ${ }^{11}$ This creation of positive peace, the presence of justice, contains many different elements and positions, and can be expressed and advocated for in numerous ways. Virginia Woolf, in her feminist pacifist polemic Three Guineas asks readers to consider the deep relation between capitalism, education, patriarchy, and war, asking pointedly,

For do they [history and biography] prove that education, the finest education in the world, does not teach people to hate force, but to use it? Do they not prove that education, far from teaching the educated generosity and magnanimity, makes them on the contrary so anxious to keep their possessions, that "grandeur and power" of which the poet speaks, in their own hands, that they will not use force but much subtler methods than force when they are asked to share them? And are not force and possessiveness very connected to war? (38)

Woolf challenges us to question, then, how we can construct a society without war. From battling racism, to addressing poverty, to pointing out gender privilege and imbalances, to answering ethical calls from refugees, the ways to undertake a construction of a positive peace are multivalent. Digital humanities, combined with peace pedagogy dedicated to a feminist ethics of care, can open 
critical and creative paths that allow students to assess, analyze, and come to terms with the complicated range and expressions of pacifist and warist positions, and engage discussions of positive peace building. Together these theories interlace to create a transformative pedagogy with an emphasis towards thinking peace.

This essay offers strategies for a peace pedagogy that is informed by combining techniques from feminist theory and peace studies with the digital humanities. Here we describe how our first-year Writing Seminar "Peace Testimonies in Literature \& Art," taught in Spring 2017 at Haverford College, collaborated with the activist organization American Friends Service Committee (AFSC) to participate in the collection and curation of oral histories projects. Foster was the primary instructor and Janco the embedded librarian of this class. Foster and Janco had collaborated on pedagogy projects in previous courses and continued this collaboration through the Spring of 2017. Janco assisted Foster in developing the technical aspects of the course, designing the assignment for use with Oral Histories Metadata Synchronizer (OHMS), worked with the students to create transcriptions, and taught classes on the usage of OHMS, an online system from University of Kentucky that allows one to index and render oral histories searchable. Oral histories themselves are radical undertakings that invite those who remain on the outside of history and academic society into its center. If history, as Michel-Rolf Trouillot says, lies somewhere between "'what happened'" and "'that which is said to have happened"' (2), and as the "process and conditions of production of such [historical] narratives" (25), then oral histories enact the recovery of those histories that lack institutional seals of approval, and create "documents" that have thus been excluded, but can now be introduced, into the archive. As Trouillot points out, the creation of history is ensconced in power dynamics, as are its silences. In a warist society, peace histories become those "muted voices" whose imperative it is for educators of peace to recover. In our class, students conducted oral history interviews of peace activists to unmute those voices at the 2017 AFSC symposium "Waging Peace: AFSC's Summit for Peace and Justice" (April 20-23 in Philadelphia, PA), and then analyzed the videos of these interviews through the Oral History Metadata Synchronizer (OHMS) and the video editing software Camtasia. We constellate a number of key terms throughout this paper: feminism/t, peace studies, pedagogy, digital humanities, and pacifism, sometimes with slippage between the categories. The variety of constellations are deliberate, for feminist theory, digital humanities, and peace studies all have their own pedagogies whose theories are complementary and overlap in interesting and generative ways. As we explain, they can all be framed under the larger umbrella of "transformative pedagogy." It is the combining of feminist thought and pedagogy, peace studies and peace pedagogy, and digital humanities and digital pedagogy that we find so fruitful here. The questions that the interplay between war and peace raise are some of the biggest moral issues to affect global citizenship, and a peace studies that engages feminist theory can help us think through some of these problematics. The pedagogies that stem from these fields, coupled with digital and feminist pedagogy, we argue, can help us teach them.

\section{Oral Histories and Partner Collaboration with the American Friends Service Committee}

It is from this background of peace studies and digital pedagogy that we engaged students in the "Peace Testimonies in Literature \& Art" course in the American Friends Service Committee oral histories. The AFSC, founded in 1917 by members of the Society of Friends (Quakers), has an established history of pacifist work. The AFSC was created "during World War I to give young conscientious objectors ways to serve without joining the military or taking lives. They drove ambulances, ministered to the wounded, and stayed on in Europe after the armistice to rebuild war-ravaged communities" (AFSC History). The AFSC has continued this mission of peace and service throughout the years. In the summer of 2016, Donald Davis, archivist of the AFSC on Cherry Street in Philadelphia, mentioned to Foster that he had always wanted to collaborate with a school on an oral histories project, recording the accounts of some of the peace activists who worked with the AFSC. Haverford College, with its Quaker roots and close proximity to the AFSC headquarters in Philadelphia, lent itself to this kind of collaboration. Foster and Davis started to dialogue about the possibility, and decided that the upcoming conference, "Waging Peace: AFSC's Summit for Peace and Social Justice," would offer an exceptional opportunity for students to conduct interviews. The scope of papers and the diversity of panelists would cast into full relief the variety of activist pacifism. Students had the opportunity to engage topics as wide ranging as the conflicts in Northern Ireland, South African Apartheid and the Cold War, Israel-Palestine relations, the Poor People's Campaign, and the Open Housing Movement, just to name a few. The Spring 2017 "Peace Testimonies in Literature \& Art" Writing Seminar was thus planned with the oral histories project in mind. Readings concerning First World War and Spanish Civil War pacifism were taught along with pacifist literature and art to prepare students with the theoretical frame that would allow them to engage their interview subjects. Studying Virginia Woolf, Langston Hughes, and Pablo Picasso connected the way in which capitalism, racism, patriarchy, and war are intertwined. Students worked in pairs or triads to read the abstracts for conference papers, research the speakers, and choose who they wanted to interview. They emailed their intended interviewees, inviting them to be involved in the project, and arranged logistics and scheduled the interview. Students created a list of questions to ask the interviewees, based on their interests concerning questions of peace and pacifist activism that had arisen during the semester. On April 21, students traveled to the AFSC, attended the conference, and conducted their interviews, which were video recorded.

The recordings were automatically transcribed using a program called PopUpArchive, which was originally intended for radio stations as a way to make their content discoverable on the Internet. That program was acquired by 
Apple in 2017 and no longer exists; however, there are a variety of current voice-to-text services such as Otter.ai as well as open-source options from Mozilla. The text output was put in individual Google Docs for the students to review and edit. The written transcriptions were then synchronized with the original video using the Oral History Metadata Synchronizer (OHMS) from the University of Kentucky. Using OHMS, we added a simple timestamp to the transcription (Boyd 2013). With two or three clicks, the machine identifies a rough correspondence between a point in the written transcription and the original video or audio. The OHMS viewer then allows researchers to search the text to find specific points in the interview. The audio and video of the interview become searchable. Additionally, students added metadata tags to the interviews to detail, at a more abstract level, clear sections and topics, adding what might be called an "index" and a "table of contents" to the video interviews. These annotation tasks called for interpretations of the interview, its periodization, and an assessment of the major topics, turning points, and notable references. This, in turn, asked students to identify what contextual information would be useful to others as they view the interview.

Using OHMS to render these oral histories searchable is an essential part of making them user-friendly to both students and scholars. Doug Boyd and Mary Larson observe in Oral History and Digital Humanities that the struggle with untranscribed oral histories is that they are difficult to access, and even more difficult to use for teaching and research:

Without the transcript, the archive might have no more information about an oral history interview on its shelves beyond a name, a date, and the association with a particular project. Archives simply do not have the time of resources to actually listen to each and every moment in each and every interview in order to provide accurate and useful descriptions of the contents to their researchers. (4)

Bringing the digital humanities and oral histories together, OHMS offers a way for students to synthesize the video and transcript text, and also provides tools for indexing and the creation of metadata. This is both reflective of the interactive engagement and production of knowledge that peace pedagogy advocates and offers students a way to create critical interventions in history. First, the students are participants in the creation of an archive of peace histories, and second, they have a scholarly contribution in the indexing and tagging of concepts, thus cataloguing the histories in meaningful ways. For example, in their interview with Doris Panzer, Jake Kutchins and Paige Walton indexed their interview transcript with titles that allow a researcher to understand the main topics of the interview: "Beginnings in Ethnographic Research"; "Background on
Conflict in Northern Ireland"; and "Peace Process and Rebuilding Efforts" give an overview of what was discussed [See Figure 1]. Keywords in each section of the index, such as "Catholic; Government; Peace; Policy; Protestant," create tags of metadata, and the "Segment Synopsis" allows students to give a quick gloss of each section of the interview [See Figure 2]. Together, these elements render the oral histories more accessible and usable, while maintaining the integrity of the importance of voice, body language, and gesture in our modes of communication. It brings the text and video together in a way that working with a video and corresponding paper transcript fails, and allows the students to use their critical facilities in cataloguing and the creation of metadata.

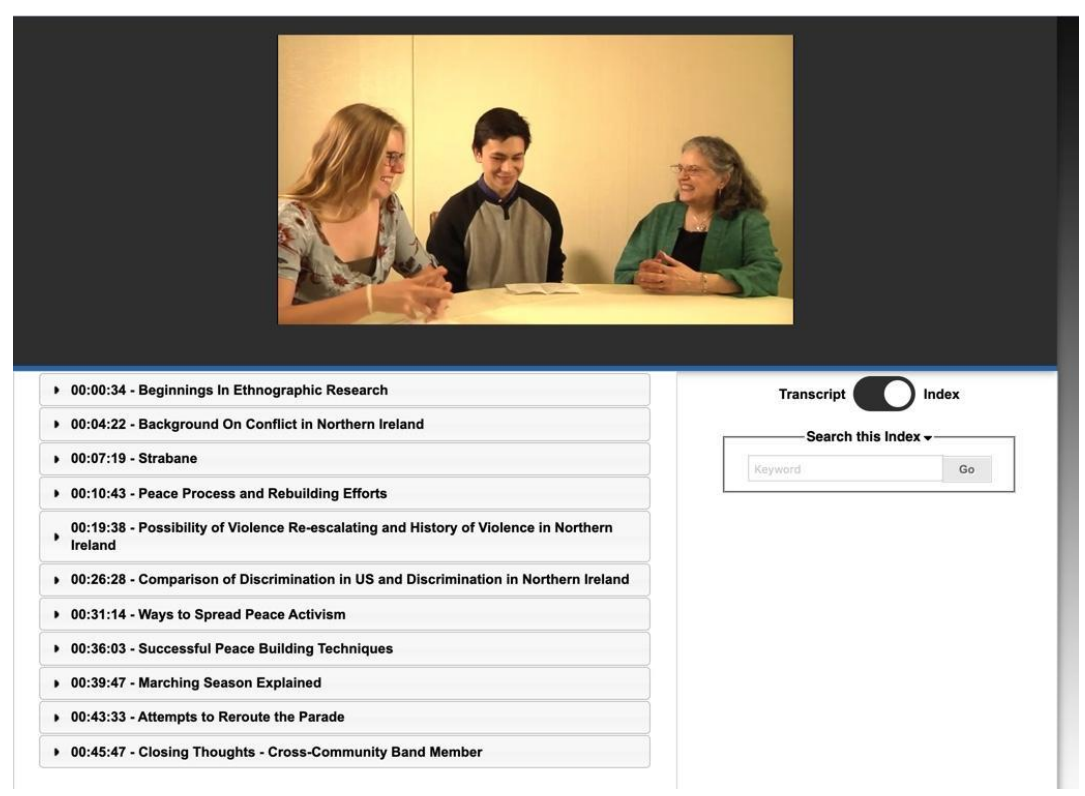

FIGURE 1. (FROM LEFT TO RIGHT) HERE, PAIGE WALTON AND JAKE KUTCHINS INTERVIEW DORIS PANZER. NOTE THE INDEX AT THE BOTTOM, THAT ALLOWS RESEARCHERS AN OVERVIEW OF THE TRANSCRIPT.

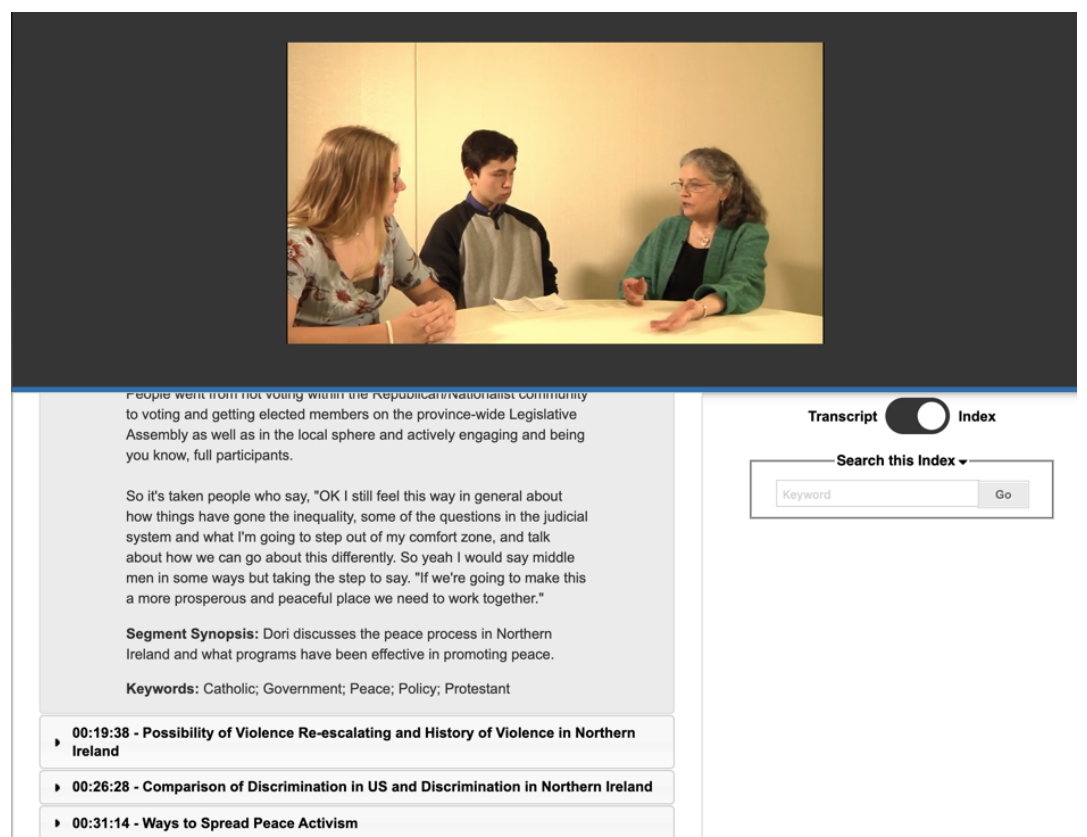

FIGURE 2. DETAIL IMAGE OF THE INTERVIEW ABOVE. NOTE HOW OHMS ALLOWS THE STUDENTS TO INCLUDE THE TRANSCRIPT, SEGMENT SYNOPSIS, AND KEYWORDS. 
Initially, we utilized automated voice transcription in an effort to focus student work on the more intellectual tasks of description and analysis. Recent advancements in machine learning make transcription affordable and nearly as accurate as human transcribers. However, the students did not engage with this technology as expected. The students needed only to comb over the text to find the occasional machine error or typo. While this seemed like an opportunity to teach proofreading and close reading skills, the students either accepted the machine's output relatively uncritically, which left the errors in place, or they started again from scratch to maintain full ownership and authorial control of the transcription. Students preferred to maintain control of the text and to transcribe the interviews by hand. The process of transcribing each word also made it easier to write more abstract summaries of the interviews and to mark distinct sections and topics.

After creating their OHMS interviews, students used Camtasia to create interpretive videos. In collaboration with Sharon Strauss from Haverford's Instructional and Information Technology Services, students chose a fiveminute segment of the video and analyzed it, adding voiceovers, context, and analysis. This is where they were able to insert historical information and commentary, and critically grapple with the material yielded from the oral histories. Foster and Strauss chose this program to allow students to have experience creating a multi-modal, creative argument. Strauss taught several class sessions on the use of Camtasia. The assignment prompt specified that the final video should contain an analysis, voice over and verbal commentaries, one moment of historical context, still images, written annotations, and a works cited list. The use of Camtasia juxtaposed with OHMS in the final stage of the project allowed the students to perform the role of critic, after they had been in the roles of interviewer, researcher, archivist, and cataloger. Camtasia is an editing program where one can interpolate other videos, still images, voice overs, and animations into the video. This gives the students both critical and creative control, and allows them to literally insert their voices into the "text" of the interview. For example, Jake Kutchins and Paige Walton set up their Camtasia video as a scene in "Real News 1." They interspersed video clips of news and information from Northern Ireland and interviews that they conducted throughout the Haverford College dorms with fellow students into their interview with Doris Panzer. They combined rich research, visual elements, and humor to create an informed and insightful video. Ari Kim and another student were able to critically engage with the interview they conducted with Dr. Carolyne Lamar Jordan, who served on the board of the AFSC and the Africa and Women's Program. This was a special interview, as Dr. Lamar Jordan has had an incredible and established career, and was very generous with her time and stories. Folded into their interview clips, Kim and another student offered historical context of the Third World Coalition (TWC), "created to address the lack of representation of POC [people of color] in the AFSC," and to interrogate, "what is the TWC's most important work today?" They poignantly and critically analyzed promotional videos from the AFSC in light of the interview, constructing a fascinating and nuanced narrative around diversity in the AFSC.

\section{Oral Histories and an Ethics of Care}

Several particular ideas from Carol Gilligan's ethics of care, peace pedagogies, and feminist digital humanities emerge from these projects. In analyzing the student work, themes of "connectedness or interdependence" (Gilligan, ethicsofcare.org), critical thinking, dialogue, giving voice, and public engagement become clear. In the oral history project with the AFSC, student initiative and community engagement were foundational. Oral histories are collaborative in nature, and bring out the feminist ethics of care. In addition to the readings concerning the First and Second World Wars and the Spanish Civil War, in order to prepare students for the oral histories and discussions that may evolve, we invited Librarian Krista Oldham and Professor James Krippner from the Department of History to speak about the ethics and considerations of conducting interviews. They also advised the students on how to construct their questions and Foster and Janco on the informed consent forms gathered from interviewees. Due to the nature of the project, it was deemed that the risk to the participants was not greater than daily living. Given that the interview subjects were scholars and researchers speaking on similar topics at the AFSC summit, the Peace Testimonies class was granted an exemption from the IRB (Institutional Review Board of Human Subject Research) process. However, students were included in this discussion of exemption, and they were aware and privy to the way in which Special Collections developed with Foster an informed consent form that all the interviewees signed. All students also signed forms expressing their willing participation in the project, solidifying Oldham's lessons around interview ethics.

Oldham pointed out to the students while they were developing research questions that oral histories are a coauthored project between the interviewer and interviewee. Because "[a] revolutionary practice of peace education attempts to strike at the root of the ideologies and conditions that perpetuate patriarchal fantasies of war and dominance" (Darder 101), we cannot forget our feminist roots in the creative interpolation of peace pedagogies in the classroom. Carol Gilligan's theoretical construct, the ethics of care, has been taken up by peace studies theorists in recent years to further develop this relationship. ${ }^{2}$ An ethic of care, according to Gilligan as described by Kimberly Hutchins, "is embedded in the practicalities of relationships of responsibility for others" (11). In other words, women's social education as caregivers have oriented them towards thinking of themselves, morality, and ethics relationally, in the context of what it means to provide and nurture life in others. In In A Different Voice, Gilligan maintains that, "in the different voice of women lies the truth of an ethic of care, the tie between relationship and responsibility, and the origins of aggression in the failure of connection" (173). She continues on, "While an ethic of justice proceeds from the premise of equality--that everyone should be treated the same--an ethic of care rests on the premise of nonviolence--that no one should be hurt" (174). From the focus on equality and nonviolence, the understanding of the interconnectedness of life and relationality of existence, and the privileging of caretaking as the gestural mode to the other, a feminist ethics of care lends essential elements to the discourses of 
peace studies and peace building. The engagement in dialogue and listening, the giving voice to the interviewee's experience and the role of the interviewer in bearing witness to this experience, develops the elements of an ethic of care. The emphasis on voice, relationships, and dialogue are consistent with the values of peace pedagogy. This ethic became really pronounced in student interviews with Tracy K'Meyer. The students started the interview with a personal gesture, admitting nervousness and asking Meyer about her first interview experience. This verbal exchange created a relation between the team of interviewees and interviewer, where students gave Meyer an opportunity to listen, respond, and share, creating the groundwork for a very generative conversation. This group of students used the interview as a way to investigate not only the Open Housing Movement, but also the nature of oral histories themselves. The students' indexing walks us through subjects such as "How Oral Histories Interact with Daily Life" and "The importance of multiple perspectives in oral histories" as well as topic-related questions like "What accounts for white panic?" and "the AFSC and black leadership." Indeed, the responsiveness here, with its listening and interactive components, encapsulates many of the steps outlined in UNESCO's "peace builders' competencies" (19), which are mentioned as:

collaboration and teamwork, self awareness, sensitivity to gender religious and cultural difference \& openness to otherness, mediation and negotiation, interpersonal and intercultural communication, critical thinking, nurturing values: respect, empathy, responsibility, and reconciliation and forgiveness, and active listening. (19)

In this interview, we see an exchange of empathy, collaboration and teamwork, self awareness, a sensitivity to difference, and interpersonal communication unfold.

The collaboration with the AFSC proceeded as part of an academic course whose aim it was to encourage students to develop their own research questions and lines of inquiry. Significant leeway was granted to the students and space was deliberately created for them to design their oral histories. They worked together to identify research questions and interview subjects that were important for them, thus having the freedom and control to develop their own research agendas. This deliberate accounting for student interests and voice builds on traditions of collaboration in the digital humanities. Given the prominence of project-based research in the digital humanities, much thought and attention have been paid to models of collaboration in the field. The most common model of collaboration in $\mathrm{DH}$ is what Tom Scheinfeldt calls the "additive" model (Scheinfeldt, 2018). A faculty member initiates a project and adds project partners to augment the professor's skills and expertise. Staff and students make prescribed contributions to the project as assigned by the Principal Investigator. Guidelines on the evaluation of digital scholarship often require this model of tenure-track faculty who need to retain the primary "authorship" of the project. While we might have adopted an "additive" approach, early discussion between Foster and Janco followed more of a partnership model and it seemed logical to extend this mode of collaboration to student work as well.
In an effort to address the hierarchy (and indeed, subverting these hierarchies are prioritized in both peace and feminist studies) of the "additive model," Alison Langmead et al. have introduced a role-based approach to collaboration (Langmead et al., 2018). This model recognizes that each of the project partners has their own intellectual research interests and professional motives. This diversity of interests and needs must be accounted for in the project design and its outcomes. Will students come away with a clear portfolio item for their resume? Will the project research new technologies or methods? If the professional or intellectual stakes for the technologist or data steward are not accounted for, then the exchange is better understood as contract labor than collaboration. Such an exchange often misses the opportunity to benefit from the full creativity and intellectual curiosity of technical partners. We might take this one step further to account for student engagement and community partnerships. What spaces are made for student initiative and interests in the design of the project and its outcomes? Are community partners engaged as co-producers of knowledge? Foster and Janco established early in their planning that a collaborative project-based approach was the best way to de-centralize authority. If there were a clear spectrum of collaboration, we could place the centralized "additive" model at one end with a completely decentralized and egalitarian model at the other extreme. Such a communal model would fully benefit from the perspective and motives of all participants. In many cases, this could be the best approach for effective collaboration, but there are often structural forces at work that demand some form of distributed authority. Additionally, for a project of this scope, Foster and Janco now recommend adjusting the syllabus of the entire class to be a project-based learning seminar, instead of introducing it as a module to a class already constructed. This would mean that the complete semester would be concentrated on the skills necessary to develop the oral histories and required technological components. These transferable skills of research, digital literacy, critical analysis, writing, and verbal communications are precisely the things that most writing seminars value and adding more tasks can overwhelm these lessons.

The "Peace Testimonies in Literature \& Art" course fulfilled the first-year writing seminar requirement for incoming students. While students had a choice as to which seminar they wanted to take, they did not have many college classes to compare it to, and sometimes this course challenged the expectations of students as to what a college class should look like. Our efforts to create spaces for student initiative and creativity were meant to appeal to a broad range of students and learning types, particularly those for whom the instructor's authority and knowledge of the subject matter are not a given. Shifting the focus of learning work to a real-world problem or tangible project such as the AFSC interviews can be highly effective. Writing for an external audience or other exercises that place student work in the world and not just the grade book can generate motivation. However, this is also not always the case and we cannot automatically assume student buy-in. One of the values that peace pedagogy espouses is "affirmation" -- according to Ian Harris, "Affirmation in the classroom helps to develop a sense of competence" (265). 
After working on the AFSC project, Foster also now believes that affirmation not only develops a sense of competence, but that it develops a warm emotional feeling between the students and the work. As previously mentioned, this semester included a number of readings on peace theory. Students at times struggled with resistance to Virginia Woolf, which then alienated a discreet few from the material. In this case, Foster's normal practice of providing more information on the subject did not help overcome this resistance. In hindsight, and with more reading on peace theory, Foster started to internalize the peaceful value of "affirmation." She realized the resistance students felt was an emotional, not necessarily an intellectual one, and they did not need more thoughts and information crowding high feelings, but space to work through the rocky terrain of the heart and the psyche. Though Janco did participate in classroom teaching, his role was specifically project-based. He worked closely with students on OHMS and their transcriptions. Due to the differing nature of the roles of Foster and Janco, they had different learning moments for their own pedagogy. Janco's experiences with the class led to the observations above concerning students' desire to have total control of their transcriptions. From her experiences, Foster adopted certain practices. When a student speaks in class and it is not a free-flowing discussion, but a response to a question or an intervention in the material, she says "thank you" and gives a bit of a pause around their comments. This recognizes the student's contribution, even if they are feeling negatively about the readings. To get a diversity of voices in the class, instead of citing other critics, Foster will now often ask if other students have alternate readings. And finally, Foster has come to understand that attending to the emotional atmosphere of a class is as valuable, if not more, than tending to the intellectual atmosphere--something that those who lead with their head often forget.

\section{She realized the resistance students felt was an emotional, not necessarily an intellectual one, and they did not need more thoughts and information crowding high feelings, but space to work through the rocky terrain of the heart and the psyche.}

In many cases, novel pedagogical approaches could be met with resistance. Students are often required to be highly strategic in how they distribute their time and energy across courses in various disciplines. An oral history project can seem relatively open-ended with unfamiliar assessment criteria and greater time demands than a traditional essay. What might seem to the instructor to be an opportunity to express creativity and assume greater responsibility for the design and implementation of a project can easily be both a source of excitement and anxiety -- excitement because the material is new and innovative, and often fun to construct, but potentially anxiety inducing because students worry about assessment and working outside of traditional modes of receiving grades. This note of caution is not an argument

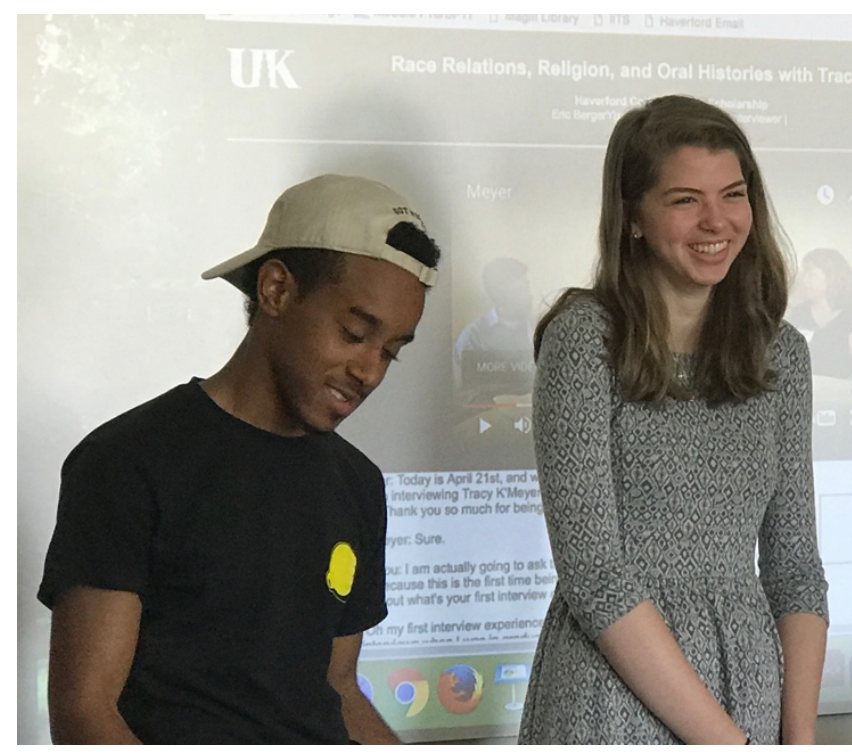

FIGURE 3. (LEFT TO RIGHT): RUDOLF HERNANDEZ AND ALYSSA KERPER PRESENT ON THE LAST DAY OF CLASS ABOUT THEIR EXPERIENCES WITH THE ORAL HISTORIES PROJECT.

against project-based teaching methods. Rather it highlights the need for coalition-building amongst various student groups in the classroom and clear communication of the instructor's values and reasoning for the assignment as planned, including specifying where the deliberate introduction of student voices into the architecture of the class project lies. One thing that Foster adopted in the years following this course is what she calls "transparent teaching" -- offering a meta-analysis of pedagogical methods and explaining to students the reasoning and logic behind assignment construction and choice.

We addressed collaboration concerns with digital pedagogy by empowering the students to pursue their own research interests and questions, thus creating unique scholarship in each case. First, students were able to choose their interview subjects from anyone who had been accepted to the conference. The diversity of speakers and topics already allowed the students to see a panorama of possible peace activist modes, and to concentrate on what specifically interested them. Instead of having a standard set of questions, which an official study would mandate, students proposed questions about ideas that they wanted to explore in depth. While constructing their questions, students were asked to research the specialties of their interviewees and compile an annotated bibliography. This allowed the students to co-construct the discourse based on research and information they had found, and the questions asked reflected the different interests of the students. For example, Rudolf Hernandez and Alyssa Kerper constructed questions for Gordon Mantler, who specializes in African American and Latino civil rights social justice movements, that had both specific and universal implications. One of their questions extended into the present day: "Given the fire the current presidential administration has come under, and the resulting marches on Washington, would the public's interest and efforts on important issues such as climate change move our political agenda forward even if President Trump does nothing to change his current plan of action?" Another of their questions was more abstract and 
philosophical, but one of the central interrogations of the class, "What do you think is the connection between ending poverty and achieving peace?" [See Figure 3] Additionally, the students were the primary investigators and interviewers in each of their own oral histories. They were not simply working on the technology after the fact of the academic discourse, but by being at the AFSC conference for the day and engaging directly with the activists and academics, were a central part of the discourse.

\section{Towards a Transformative Pedagogy of Peace Studies}

Haverford College is a small, elite liberal arts college with an amazing amount of resources and a vibrant embedded librarianship and instructional technology support system. While a great deal of energy and resources were dedicated to this project in order to ally with the ASFC, there are also less intensive ways of folding oral histories of positive peace building into a multiplicity of classes at colleges that may not share Haverford's privileges. Students could be assigned to interview local activists or citizens within their immediate community working on social justice and human rights issues. Classes could partner with public libraries in community collaborations to include oral histories in their course work. For an interested radical teacher, we recommend starting with the Oral Histories Association guide of principles and best practices, most recently updated in 2018. It also behooves us to remember that building peace does not always mean the most elaborate or public engagement; it does not always mean attending a rally or serving in an international program or movement; sometimes peace building occurs in the granular and everyday habits of existence. Sometimes planting a beautiful garden for neighbors to see is peace building; sometimes raising a family sensitive to the call for equality and human rights is peace building. Peace building does not need to be grand, and indeed most of its important elements are in the everyday simplicities of kindness and the ethics of care. From that perspective, students could do oral histories on each other and loved ones that interrogated the work they are already doing in the world to build peace. They could then take these videos, shot on a phone or tablet, and render them searchable through OHMS (available online for free) or any of the numerous free video-editing programs.

From the experiences and approaches outlined in this article, we have come to understand that combining digital, feminist, and peace pedagogies opens onto a transformative pedagogy that allows students to move beyond the absorption model of education and become key producers of knowledge and researchers in their own right. Transformative pedagogy, according to UNESCO's Transformative Pedagogy for Peace Building, allows students to internalize the material so that the learning extends beyond the classroom. Indeed, the study writes:

A transformative pedagogy is an innovative approach that occurs when learning goes beyond the mind and connects also with hearts and actions thereby transforming knowledge, attitudes and skills... Transformative pedagogy also emphasizes and prioritizes the process of learning (how to learn) [rather] than the association and memorizing of information itself: fostering the curiosity of the learners is more important than delivering knowledge and information. (Adaye 27)

As the title indicates, UNESCO's guide advocates for using approaches towards peace building that center on process, student engagement and participation, and critical thinking. Peace pedagogy is collaborative in nature, sparks dialogue in a multiplicity of ways (within the classroom, between the classroom and community, between different groups and demographics), encourages critical and creative thinking, and is active and participatory. ${ }^{3}$

Students took these projects and transcended our vision every time, expanding it and making the work better than anything that could have been anticipated. Furthermore, students were able to form personal relationships with individuals that personify peace activism and pacifist ethics of care. Through social interaction with the AFSC symposium speakers, students had the opportunity to encounter pacifism as lived practice and critically reflect on warist culture. Through the oral histories project with the AFSC, students were able to explore the multifaceted ways of building peace. Through OHMS and Camtasia, they devised creative and critical ways to add to an archive of pacifist activism that is severely underdocumented. The Oral Histories are currently available from Haverford Libraries Digital Scholarship and should be available from the $\mathrm{Bi}$-College digital archives with a password when that service is completed. A definite majority of the students acknowledged the pedagogical benefits of the project, and their comments ranged from specific growth in researching and questioning to deeper self-discoveries. It became clear that the combination of oral histories with the technology facilitated the most growth. Henry Nye wrote about his final paper that:

The OHMS and Camtastia portion of this Oral Histories project were new to me, and very exciting on the whole. I felt that being able to watch an interview whose usefulness I originally questioned was very helpful for me to tease out some important thoughts... Further, I believe I made a nearly opposite argument in this paper than I did in the Camtasia project, which was an interesting dialectical experience that I don't believe I could've achieved without deep engagement in the OHMS project."

\section{Ari Kim wrote that:}

The entire project was very insightful for me, both on life and on academia. I was blown away by my interview with Dr. Carolyne Lamar Jordan. She is a phenomenal woman who has done amazing work. Although [my interview partner] and I expected more answers relating to Dr. Jordan's abstract, the experiences she shared were far more interesting and inspiring. The idea of co-creation in the interview, and in the OHMS and Camtasia projects with [my interview partner], gave me a new perspective on academic content. I've always been taught to be the sole creator of some cutting-edge idea or invention, but working with others, as this project has proved, gives birth to something more 
fantastic than what only one mind can create. The entire process was also a lot more bearable having someone else with me than working alone.

Thank you for the opportunity to work on this project. It has truly been a blessing.

From the language of this student, we can see the feminist ethics of care developing. Emphasis on co-creation and cooperation, on listening and response, was developed through the oral histories, and OHMS and Camtasia facilitated a deep critical thinking. These same values-connection, listening and responding, cooperative engagement with others, and a respect for the diversity of stories and experiences that make up human existence--are also foundational to peace pedagogies, and combine with feminist thought to encourage a transformative pedagogy that asks us to think the multiple meanings of peace in the wake of a warist society.

\section{Acknowledgements}

Our deep gratitude goes to the students of the "Peace Testimonies in Literature \& Art" Spring 2017 Writing Seminar. Their engagement and creativity made this project possible. We would also like to express sincere thanks to the AFSC and Don Davis for facilitating this fruitful collaboration, and to all the participants of the "Waging Peace" 2017 summit who agreed to be interviewed. Our appreciation goes to the Haverford College Libraries and Instructional \& Information Technology Services, whose staff was instrumental in making this project happen, and to our funding sources at the Hurford Center of the Humanities and the Center for Peace and Global Citizenship. Early sections of this paper were presented at the 2017 symposium "Remembering Muted Voices: Conscience, Dissent, Resistance and Civil Liberties in World War I through Today," held in Kansas City, MI, October 19-22.

\section{Notes}

1. Also quoted in Lynch, xv.

2. See for example Fitz-Gibbon, Hutchins, and Gay.

3. Our understanding of peace pedagogy is informed by several important sources in addition to the UNESCO Transformative Pedagogy guide. Setiadi et al., in their study of implementing peace programs in Indonesian schools, cite SL Deck in "Transforming High School Students into Peacebuilders: A rationale for the Youth Initiative model of peace education," to identify five main components to peace pedagogy: "transformative, process-centered, participatory, relational and sustainable" (183). Ian Harris likewise identifies five important elements to peace pedagogy that are sympathetic to the aforementioned: "dialogue, cooperation, problem solving, affirmation, and democratic boundary setting" (255).

\section{Works Cited}

Adaye, Yonas. Transformative Pedagogy for Peace-Building: A Guide for Teachers. Addis Abba: UNESCO-IICBA, 2017.

American Friends Service Committee. "Waging Peace: AFSC's Summit for Peace and Justice." Symposium. Philadelphia, PA: April 20-23, 2017.

"AFSC History." American Friends Service Committee. https://www.afsc.org/afsc-history

Boyd, Douglas A. "OHMS: Enhancing Access to Oral History for Free" Oral History Review 40.1 (2013): 95-106.

Boyd, Douglas A. and Mary A Larson. "Introduction." Oral History and Digital Humanities: Voice, Access, and Engagement. Ed. Douglas A. Boyd and Mary A. Larson. New York: Palgrave Macmillan, 2014. 1-16.

Cady, Duane L. From Warism to Pacifism: A Moral Continuum. Philadelphia: Temple UP, 2010.

Crawford, Neta C. "Human Cost of the Post-9/11 Wars: Lethality and the Need for Transparency." Providence: Watson Institute, 2018. https://watson.brown.edu/costsofwar/files/cow/imce/p apers/2018/Human $\% 20$ Costs $\% 2$ C $\% 20$ Nov $\% 208 \% 202$ 018\%20CoW.pdf

Dardar, Antonia. "Dreaming of Peace in a Culture of War." Pedagogy, Philosophy, Politics: Interrogating Peace and Peacemaking. Ed. Carmel Borg and Michael Grech. London and New York: Bloomsbury, 2018.

Fitz-Gibbon, Jane Hall. "Of Course, God is a Man! Masculinist Justifications of Violence and

Feminist Perspectives." Pacifism, Politics, and Feminism: Intersections and Innovations. Ed. Jennifer Kling. Leiden and Boston: Brill Rodopi, 2017.

Gay, William C. "Pacifism, Feminism, and Nonkilling Philosophy: a New Approach to Connecting Peace Studies and Gender Studies." Pacifism, Politics, and Feminism: Intersections and Innovations, Ed. Jennifer Kling. Leiden and Boston: Brill Rodopi, 2019. 137-154.

Gilligan, Carol. In A Different Voice: Psychological Theory and Women's Development. Cambridge and London: Harvard UP, 1982.

---------. "Care Ethicists-Network: Carol Gilligan". Ethics of Care: Sharing Views on Good Care. 16 July 2011, https://ethicsofcare. org/carol-gilligan/.

Harris, Ian M. "Principles of Peace Pedagogy." Peace \& Change 15.3 (1990): 254-271.

Hutchings, Kimberly. "Ethics, Feminism and International Affairs." In Jean-Marx Coicaud and

Daniel Warner (Eds) Ethics and International Affairs: Extent and Limits 2nd Edition. Tokyo \& New York: United Nations University Press: (2013). 199-217. Online edition:

https://qmro.qmul.ac.uk/xmlui/bitstream/handle/1234 56789/8120/HUTCHINGS\%20Ethics\%20and\%20Intern ational\%20Affairs\%202013.pdf? sequence $=2$.

King, Dr. Martin Luther. "Letter from a Birmingham Jail." 16 April 1963. African Studies Center--University of (cc) EY-NC-ND

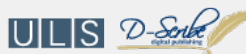

This work is licensed under a Creative Commons Attribution-Noncommercial-No Derivative Works 3.0 United States License. This journal is published by the University Library System of the University of Pittsburgh as part of its D-Scribe Digital Publishing Program, and is cosponsored by the University of Pittsburgh Press.

RADICALTEACHER 
Pennsylvania.

https://www.africa.upenn.edu/Articles_Gen/Letter_Bir mingham.html

Langmead, A., T. Berg-Fulton, T. Lombardi, D. Newbury, and C. Nygren. "A Role-Based Model for Successful Collaboration in Digital Art History." International Journal for Digital Art History, no. 3, July 2018.

Lynch, Jake. "Forward." Peace Journalism Principles and Practices: Responsibility Reporting Conflicts, Reconciliations, and Solutions. Ed. Steven Youngblood. New York and London: Routledge 2017.

"OHA Principles and Best Practices." Oral History Association. Oct 2018, https://www.oralhistory.org/principles-and-bestpractices-revised-2018/

Saint-Amour, Paul. Tense Future. Oxford and New York: Oxford UP, 2015.

Scheinfeldt, Tom. "Collaboration and Emergent Knowledge at Greenhouse Studios." Found History, 26, September 2018, https://foundhistory.org/2018/09/collaborationand-emergent-knowledge-at-greenhouse-studios/

Setiadi, Riswanda, Sunaryo Kartadinata, Ilfiandra and Ayami Nakaya. "A Peace Pedagogy

Model for the Development of Peace Culture in An Education Setting." The Open Psychology Journal. 10 (2017): 182189.

Trouillot, Michel-Rolf. Silencing the Past: Power and the Production of History. Boston: Beacon Press, 2015.

Woolf, Virginia. Three Guineas. Annotated and Introduced by Jane Marcus, Ed. Mark Hussey. Orlando: Harcourt, 2006. 